\title{
INFLUENCE OF THE DEGREE OF ADAPTABILITY AND LIFESTYLE ON THE QUALITY OF LIFE OF MEDICAL UNIVERSITY STUDENTS
}

\author{
Koroleva AA®, Yanushanets OI, Petrova NA, Bezzubenkova EF
}

Mechnikov North-Western State Medical University, Saint Petersburg, Russia

\begin{abstract}
Adaptive capabilities of young people enrolling at higher education establishments differ from person to person. Depending on the level of these capabilities, a new student may see his/her quality of life deteriorating and a variety of diseases developing. Against this background, investigation of the dynamics of students' adaptation to studying at a higher educational establishment acquires special urgency: the results of such an investigation would enable designing an effective psychological support program for such students. This study aimed to investigate how the quality of life of students changes as studying at a higher education establishment alters their degree of adaptation and lifestyle. The report compares the studied degree of adaptability and quality of life of the same group of students in their first and third years. By design, the study was prospective continuous; it involved 120 students. M. Gavlinova's two-factor questionnaire (SA, social-ANS) enabled study of the degree of adaptability. As for the quality of life of the participating students, it was registered with the help of the SF-36 questionnaire. Lifestyle of the students was assessed relying on the questionnaire designed to uncover the person's attitude to smoking, alcohol, drugs, physical culture and sports. The results obtained enabled development of recommendations aimed at identifying students running risks of maladjustment and illnesses with the aim to render such students targeted medical and psychological assistance and adjust the sanitary and epidemiological conditions of studying.
\end{abstract}

Keywords: quality of life, adaptability, vegetative resilience, medical students, healthy lifestyle.

Author contribution Yanushanets OI carried out statistical processing of the research results, reviewed the article critically and approved its final version for publication. Petrova NA, Koroleva AA, Bezzubenkova EF processed the research results reflecting the degree of adaptation of third-year students, analyzed the changes in their condition that occurred through the 2 years of studying, interpreted the results.

Compliance with ethical standards: Each participant signed a voluntary informed consent form. The students participated voluntarily, through filling in questionnaires online. The study conformed to the biomedical ethics requirements and did not endanger the participants.

$\varangle$ Corresponding author: Anastasia Alekseevna Koroleva

Piskarevsky prospect, 47, pav. 35, St. Petersburg, 195067; koroleva.gdip@gmail.com

Received: 17.04.2021 Accepted: 29.05.2021 Published online: 23.06.2021

DOI: 10.24075/rbh.2021.011

\section{ВЛИЯНИЕ СТЕПЕНИ АДАПТИРОВАННОСТИ И ОБРАЗА ЖИЗНИ НА КАЧЕСТВО ЖИЗНИ СТУДЕНТОВ МЕДИЦИНСКОГО УНИВЕРСИТЕТА}

А. А. Королева ${ }^{凶}$, О. И. Янушанец, Н. А. Петрова, Е. Ф. Беззубенкова

Северо-Западный государственный медицинский университет им. И. И. Мечникова, Санкт-Петербург, Россия

К обучению в высшем учебном заведении приступают подростки с различным уровнем адаптационных возможностей организма, которые определяют возможное формирование низкого качества жизни и развитие различных заболеваний. В этой связи исследование динамики процесса адаптации студентов к обучению в высшем учебном заведении приобретает особую актуальность, поскольку предоставляет возможность на основе полученных результатов построить эффективную программу психологического сопровождения студентов. Целью исследования явилось изучение влияния изменений степени адаптированности и образа жизни в процессе обучения на качество жизни студентов. В работе представлено сравнение результатов исследования степени адаптированности и качества жизни одних и тех же студентов на первом и третьем курсе. Проспективное сплошное исследование включало опрос 120 студентов. Изучение степени адаптированности проводилось с использованием двухфакторного опросника (СВ “социум-вегетатика»), разработанного М. Гавлиновой. Качество жизни студентов изучалось с помощью опросника SF-36. Oбраз жизни студентов оценивали на основе анкеты, включающей вопросы об отношении к курению, употреблению алкоголя, наркотических веществ и занятий физической культурой и спортом. Полученные результаты позволили разработать рекомендации, направленные на выявление студентов, относящихся к группе риска развития дезадаптации и болезни, с целью оказания им адресной медико- психологической помощи и корректировки санитар-эпидемиологических условий обучения.

Ключевые слова: качество жизни, адаптированность, вегетативная устойчивость, студенты-медики, здоровый образ жизни.

Вклад авторов: О И. Янушанец провела статистическую обработку результатов исследования, осуществила критический пересмотр содержания статьи и утвердила окончательный ее вариант для публикации. Н. А. Петрова, А. А. Королева, Е. Ф. Беззубенкова провели обработку результатов исследования по части адаптированности студентов третьего курса и проанализировали изменение их состояния в динамике за 2 года, интерпретировали результаты.

Соблюдение этических стандартов: добровольное информированное согласие было получено для каждого участника. Проведение онлайн-опроса проводилось на добровольной основе с использованием онлайн-сервиса. Исследование соответствовало требованиям биомедицинской этики и не подвергало опасности участников.

$\bigotimes$ Для корреспонденции: Анастасия Алексеевна Королева

Пр. Пискарёвский, д. 47, пав. 35, г. Санкт-Петербург, 195067; koroleva.gdip@gmail.com

Поступила: 17.04.2021 Статья принята к печати: 29.05.2021 Опубликована онлайн: 23.06.2021

DOI: $10.24075 /$ rbh.2021.011 
The first three years at a medical university are considered difficult for the students. There are numerous factors that force students to mobilize and adapt to the new living and learning conditions, including high mental and psycho-emotional load, new interpersonal relationships outside their families, selfreliance in overcoming difficult life situations, frequent violations of the regime of work, rest and nutrition, change of the place of residence etc. Not all students cope with the difficulties of studying in a higher education establishment well; some suffer deterioration of their psychoemotional state, health and, ultimately, quality of life (QOL) $[1,2]$. Today, the QOL problem is a subject of interest for most researchers from various scientific domains. In the recent years, there have been published many papers investigating QOL of the student youth, which is a special social group characterized by a specific age range, lifestyle, mentality and high intensity of the mental work done in the context of studying [3]. As a rule, QOL indicators are taken as a reflection of the person's satisfaction with his/her life and the degree of realization of his/her needs [4]. In hygienic studies, $\mathrm{QOL}$ is considered to be an attribute showing the efficacy of preventive and therapeutic measures aimed at maintaining and strengthening health of the student youth $[5,6,7,8]$. In this context, it is important to consider the dynamics of QOL indicators factoring in the individual adaptive capabilities and lifestyle change rate. However, there are but a few studies published to date that investigate QOL dynamics as it depends on the changes in the degree of adaptation and lifestyle of a student attending a higher education establishment, while observing the QOL indicator dynamics can enable development of recommendations aimed at identifying students running risks of maladjustment and illnesses with the aim to render such students targeted medical and psychological assistance.

\section{MATERIALS AND METHODS}

The SF-36 questionnaire was employed to study the students' QOL. The questionnaire measures the physical component of health with 4 scales: physical functioning, role physical (role functioning depending on the physical state); bodily pain, general health and mental health, including mental health scales; role emotional (role functioning depending on the emotional state); social functioning and vitality. The results were compared with the standard values of QOL indicators [3].

Information about lifestyle of students of the medical university's medical-preventive faculty was obtained with the help of questionnaires. The questionnaire included questions about attitudes towards smoking, physical culture and sports, use of alcohol and drugs.

M. Gavlinova's two-factor questionnaire (SA, social-ANS) enabled study of the degree of adaptability [9]. The level of social adaptation and vegetative stability was assessed. Based on the results of the SA test, all the participants were divided into groups with different adaptive capabilities: students showing high levels of social adaptation and a low level of autonomic lability were assigned to the first group A (adapters); students with normal levels of social adaptation and autonomic lability were assigned to the second group N (students with average abilities); students with manifesting social communication problems and autonomic lability within the normal range were combined into the third group B (psychotics). The fourth group, C, consisted of students with increased vegetative lability and without problems of social communication $\mathrm{C}$ (neurotics). The fifth group, D, united students who had low social adaptability and high autonomic lability (maladaptants).

Statistical analysis of the research results was performed in MS Excel 2010 and Statistica 8 software. At the first stage, the data were analyzed for normal distribution with the ShapiroWilk and Kolmogorov-Smirnov tests. With the data distribution being normal, its further processing relied on the methods of parametric statistics: Student's t-test and $\times 2$ test designed to compare two independent samples, McNemar's test for related samples. The critical level of reliability of the null hypothesis was taken as $\mathrm{p} \leq 0.05$ ( $95 \%$ significance level). The prospective continuous study recruited 120 third-year students of the medical university's medical-preventive faculty; the students filled in the questionnaires. The data obtained were compared with the results of a study that involved the same group of students when they were in their first year.

\section{RESULTS}

Figure 1 presents the results of comparison of the degree of adaptation of students as it changed from their first to third years. As the material shows, through the 3 years covered by the study the share of students able to quickly and adequately respond to changing conditions (group $A$, adapters) has decreased by 4.8 times: by the third year, only $5 \%$ of the students could be assigned to group A. Such a decrease in adaptability among students who initially show high adaptive capabilities indicates that the level of load is very high and exceeds the capacities of their bodies. At the same time, 25\% of the third-year participants belonged to group $\mathrm{N}$, average capabilities, which marks a slight increase in this group's count compared to the first year. The almost twofold growth of group $\mathrm{B}$, psychotics, is a highlight of the comparison: by the third year, $37.5 \%$ of the participating students were assigned to this group. This fact suggests lack of communication skills among modern students and/or their exposure to high levels of psycho-emotional stress in the process of adaptation to studying at a higher education establishment. Such students need additional examination by a psychologist, a program of psychological correction or training. By the third year, the share of students who consider themselves ill and present a large number of complaints of various nature, i.e., the neurotics (group C), increased by 1.5 times to $24.17 \%$. Individual characteristics and state of health of such students make them intolerant to increased loads of any nature, they need additional examination and health improvement procedures (Figure 1).

At the same time, by the third year the share of students completely maladapted, unable to cope with the educational and life loads, feeling ill, i.e., students assigned to group D (maladapted), decreased 1.8 times and amounted to $8.3 \%$. This means that by the third year at the higher education establishment, some of the students with low adaptive potential managed to cope with the educational load and organize their life. The presented data reveal that the structure of the degree of adaptation of students changes by the third year of study, since no significant differences were found (Figure 2).

Lifestyle of the students changed significantly through their years at the higher education establishment. The research revealed that the share of students with the bad habit of smoking increased by 2.3 times and amounted to $27.5 \%$. The share of students who abuse alcohol (take it more often than once a week) has also grown 2.8 times and equaled $40.0 \%$. Among the third-year students of the medical-prophylactic faculty, $6.8 \%$ have tried narcotic substances, which marks 2.2-fold growth over the first year of the same students.

Table 1 shows comparison of the QOL indicators of the medical university's medical-preventive faculty students in their first and third years. The data indicates that by the third year, no students had their physical functioning (PF) limited by 


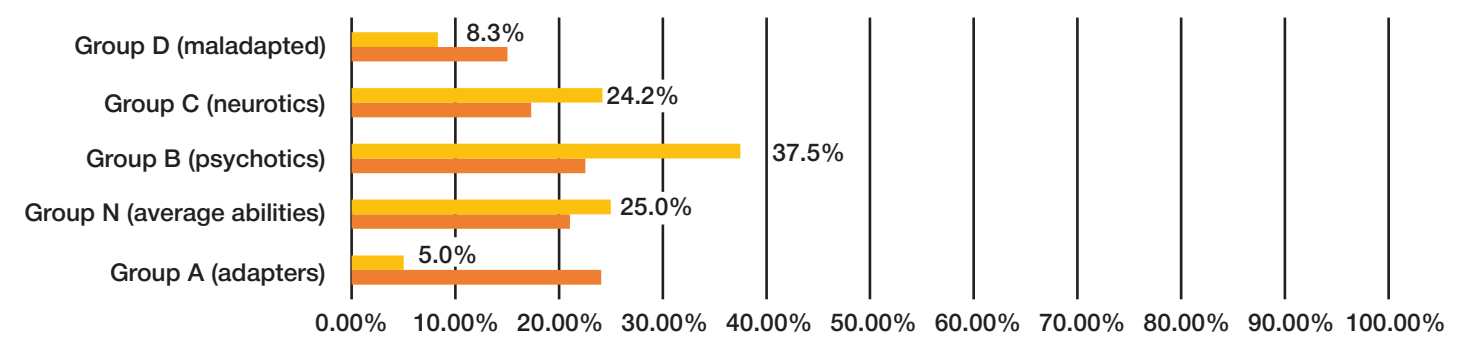

\begin{tabular}{|c|c|c|c|c|c|}
\cline { 2 - 5 } \multicolumn{1}{c|}{} & $\begin{array}{c}\text { Group A } \\
\text { (adapters) }\end{array}$ & $\begin{array}{c}\text { Group N } \\
\text { (average abilities) }\end{array}$ & $\begin{array}{c}\text { Group B } \\
\text { (psychotics) }\end{array}$ & $\begin{array}{c}\text { Group C } \\
\text { (neurotics) }\end{array}$ & $\begin{array}{c}\text { Group D } \\
\text { (maladapted) }\end{array}$ \\
\hline Year 3 (2021) & $5.0 \%$ & $25.00 \%$ & $37.50 \%$ & $24.17 \%$ & $8.33 \%$ \\
\hline Year 1 (2018) & $24.06 \%$ & $21.05 \%$ & $22.55 \%$ & $17.30 \%$ & $15.04 \%$ \\
\hline
\end{tabular}

Year 3 (2021) प Year 1 (2018)

Figure 1. Structure of the degree of adaptation, 2018 through $2021, \%$

$\square$ Year 1 (2018) - Year 3 (2021)

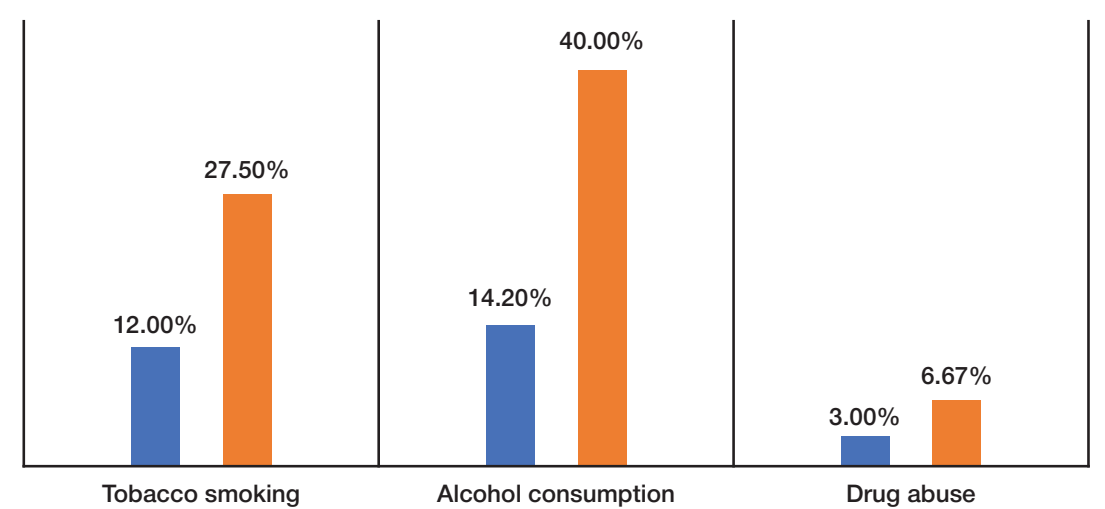

Figure 2. Changes in the share of students with bad habits, 2018 through 2021,\%

Table 1. Comparison of the distribution of students by the level of QOL, first to third years at the higher education establishment, \%

\begin{tabular}{|c|c|c|c|c|c|c|}
\hline \multirow{3}{*}{ QOL indicator } & \multicolumn{6}{|c|}{ Students' QOL level,\% } \\
\hline & \multicolumn{2}{|c|}{ Low } & \multicolumn{2}{|c|}{ Average } & \multicolumn{2}{|c|}{ High } \\
\hline & $\begin{array}{c}\text { Year one } \\
(2018)\end{array}$ & $\begin{array}{c}\text { Year three } \\
(2021)\end{array}$ & $\begin{array}{c}\text { Year one } \\
(2018)\end{array}$ & $\begin{array}{c}\text { Year three } \\
(2021)\end{array}$ & $\begin{array}{c}\text { Year one } \\
(2018)\end{array}$ & $\begin{array}{c}\text { Year three } \\
(2021)\end{array}$ \\
\hline Physical functioning (PF) & $\begin{array}{c}11.0 \\
(n=21)\end{array}$ & $\begin{array}{c}0.0 \\
(n=0)\end{array}$ & $\begin{array}{c}0.0 \\
(n=0)\end{array}$ & $\begin{array}{c}0.0 \\
(n=0)\end{array}$ & $\begin{array}{c}89.0 \\
(n=112)\end{array}$ & $\begin{array}{c}100.0 \\
(n=120)\end{array}$ \\
\hline Role physical (RP) & $28.8(n=38)$ & $\begin{array}{c}15.0 \\
(n=18)\end{array}$ & $0.0(n=0)$ & $\begin{array}{c}0.0 \\
(n=0)\end{array}$ & $71.2(n=95)$ & $\begin{array}{c}85.0 \\
(n=102)\end{array}$ \\
\hline Bodily pain (BP) & $16.1(n=70)$ & $\begin{array}{c}5.8 \\
(n=7)\end{array}$ & $31.4(n=21)$ & $\begin{array}{c}33.3 \\
(n=40)\end{array}$ & $52.5(n=42)$ & $\begin{array}{c}60.8 \\
(n=73)\end{array}$ \\
\hline General health $(\mathrm{GH})$ & $29.7(n=44)$ & $\begin{array}{c}6.6 \\
(n=8)\end{array}$ & $37.3(n=50)$ & $\begin{array}{c}48.3 \\
(n=58)\end{array}$ & $33.0(n=40)$ & $\begin{array}{c}45.0 \\
(n=54)\end{array}$ \\
\hline Vitality (VT) & $59.3(n=79)$ & $\begin{array}{c}18.3 \\
(n=22)\end{array}$ & $29.7(n=40)$ & $\begin{array}{c}51.6 \\
(n=62)\end{array}$ & $11.0(n=15)$ & $\begin{array}{c}30.0 \\
(n=36)\end{array}$ \\
\hline Social functioning (SF) & $24.0(n=68)$ & $\begin{array}{c}5.8 \\
(n=7)\end{array}$ & $25.0(n=33)$ & $\begin{array}{c}35.8 \\
(n=43)\end{array}$ & $51.0(n=32)$ & $\begin{array}{c}58.3 \\
(n=70)\end{array}$ \\
\hline Role emotional (RE) & $45.8(n=61)$ & $\begin{array}{c}34.1 \\
(n=41)\end{array}$ & $16.9(n=22)$ & $\begin{array}{c}43.3 \\
(n=52)\end{array}$ & $37.3(n=50)$ & $\begin{array}{c}22.5 \\
(n=27)\end{array}$ \\
\hline Mental health $(\mathrm{MH})$ & $41.5(n=33)$ & $\begin{array}{c}37.5 \\
(n=45)\end{array}$ & $33.9(n=45)$ & $\begin{array}{c}50.0 \\
(n=60)\end{array}$ & $24.6(n=55)$ & $\begin{array}{c}12.5 \\
(n=15)\end{array}$ \\
\hline
\end{tabular}




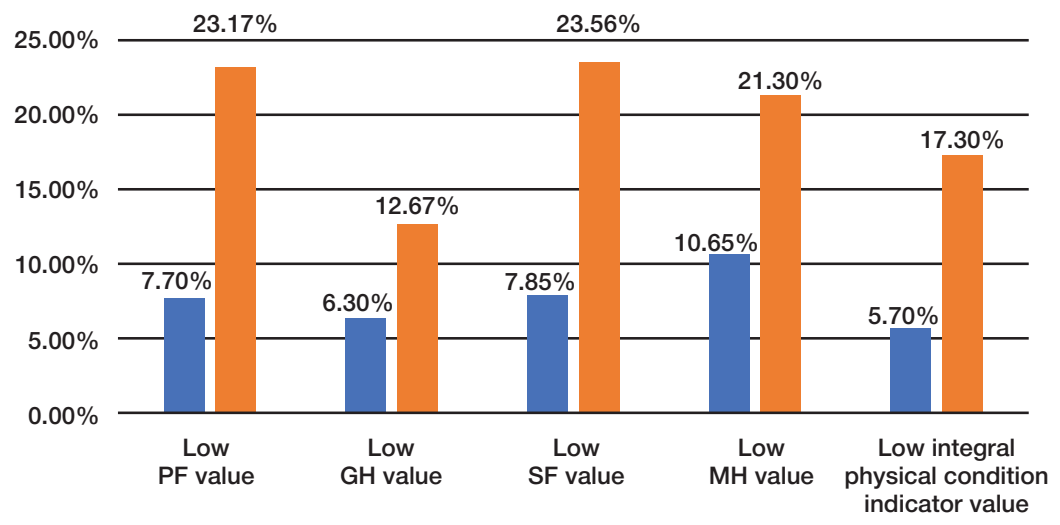

\begin{abstract}
Figure 3. Influence of the degree of adaptation on the QOL indicators
\end{abstract}
Adapters

the state of health, while at the first year, the share of those without such limitations was $89.0 \%$, which marks the growth of 1.12 .

The share of students whose physical condition does not limit role functioning (RP) increased slightly from $71.2 \%$ to $85.0 \%$. (differences insignificant). At the first year, $16.0 \%$ of students reported bodily pain (BP) that significantly limited their daily activity; by the third year, their number decreased to $5.8 \%$. $(P \leq 0.05 \mathrm{M}=3.4)$. The majority of third-year students do not experience pain (60\%). However, it is noteworthy that a third of students (33.3\%) experience various pain sensations. Compared to their first year, third-year students reported their general health as bad 4.4 times less often, the share of such assessments decreased from $29.70 \%$ to $6.67 \%$, while $48.30 \%$ stated their general health to be at the average level and only $45.00 \%$ believed it was good $(P \leq 0.05 M=7.3)$.

Noteworthy is the 2.7-fold increase (third year over first year) in the number of students who feel full of strength and energy (VT). In percents, the share has grown from $11.0 \%$ to $30.0 \%$. On the other hand, the share of students reporting poor vitality decreased 3.2-fold, from 59.3\% to 18.34\% ( $\mathrm{P} \leq 0.05 \mathrm{M}=5.2)$. Such dynamics of this QOL indicator suggests that the majority of students have their learning and living conditions organized satisfactorily. The number of students whose physical or emotional state impose no limitations on their social functioning (SF) has grown by $7.3 \%$, from $51.0 \%$ to $58.33 \%$, by the third year at the higher education establishment. The number of students whose physical and emotional state limits their social functioning has dropped 4 times $(P \leq 0.05 \mathrm{M}=6.3)$.

Dynamics of the RE (role emotional, role functional depending on the emotional state) indicator also deserves a note: at the age norm level, it was registered 2.5 times more often by the third year compared to the first, the growth from $16.90 \%$ to $43.33 \%(P \leq 0.05 M=3.3)$. At the same time, the number of students that had previously reported high values of this indicator has decreased by 1.6, from $37.3 \%$ to $22.5 \%$. Comparison of the $\mathrm{MH}$ (mental health) indicator values obtained at the first and third years has shown that by the third year, the number of students whose mental background is dominated by positive emotions has grown by $12.1 \%$. However, the number of students whose mood was mostly low and emotions predominantly negative has also increased 1.4 times, from $33.9 \%$ to $50.0 \%$. The number of students who have depressive, anxious experiences has decreased by $4 \%$, which indicates their psychological distress.

It is fair to assume that a student with a low level of adaptability will have unsatisfactory QOL indicators. Figure 3
Maladapted

visualizes the analysis of influence of the degree of adaptation on the QOL indicators of the third-year students.

As the presented material shows, among the group $D$ (maladapted) students there are 3 times more of those with low PF values than among the students that adapt well $(P=0.03, x 2=3.6)$. The difference in the $\mathrm{GH}$ values is 2 -fold $(P=0.03, x 2=4.5)$, that in the SF values is 3 -fold $(P=0.04$, $\mathrm{x} 2=2.8$ ) The number of students with low $\mathrm{MH}$ values is $200 \%$ greater in group $D$ than in the group of students with good adaptive capabilities, this difference being significant $(P=0.02$, $x 2=2.5)$. The result are the determined significant differences in occurrence of low QOL indicator values by the integral criterion: physical condition of the maladapted students is 3 times worse than that of the students with good adaptive abilities $(P=0.02$, $\mathrm{x} 2=6.3)$.

The research shows that smoking increases the number of students reporting the following $\mathrm{QOL}$ indicator values as low: $P F-1.7$-fold increase $(P=0.03, x 2=3.5), R P-2$-fold increase $(P=0.03, x 2=3.5), G H-1.1$-fold increase $(P=0.03$, $x 2=6.1)$. The growth is significant. Smoking also contributes to deterioration of the mental health QOL indicator. The share of smoking students whose integral $\mathrm{MH}$-dependent QOL criterion is low equals $42.25 \%$, which is 1.3 times greater than that in the group of non-smokers.

Alcohol brings the whole range of QOL criteria values down. Students abusing alcohol reported poor PF values 6.4 times more often $(P=0.03, x 2=3.5)$. A similar situation is observed for such criteria as RP, where low values were reported 1.4 times more often $(P=0.03, x 2=3.5)$; $\mathrm{GH}$, with the low values reported 1.2 times more often $(P=0.03, x 2=6.1) ; \mathrm{MH}$ and conditions showing presence of depression and anxiety, for which the participating students abusing alcohol reported low values 1.3 times more often $(\mathrm{P}=0.004, \mathrm{x} 2=1.0)$.

The use of narcotic substances also has an negative effect on the QOL indicators. The share of students abusing drugs and reporting low PF values is $75 \%$, which is 7.3 times more than among the students not using drugs $(P=0.03, x 2=6.4$,$) .$ Drug-using students report low values of the following criteria: $\mathrm{RP}-3.1$ times more often $(\mathrm{P}=0.02, \mathrm{x} 2=3.4) ; \mathrm{GH}-2.4$ times more often $(P=0.02, x 2=6.2) ; \mathrm{VT}-1.2$ times more often $(P=0.02, x 2=3.4), R E-1.2$ times more often $(P=0.02$, $x 2=2.84)$. All comparisons here are made with the values reported by the participating students not taking drugs. It should be emphasized that the number of students with low values for the above indicators reaches 75\%. Drug abuse was not found to influence the integral $\mathrm{MH}$-dependent $\mathrm{QOL}$ indicator. 
The research supports the positive effect sports have on the QOL indicators. Comparing students that go in for sports and those who do not through the lens of the QOL indicators, we established that the latter reported low values thereof considerably more often, specifically: PF -5.2 times more often $(P=0.02, x 2=6.4) ; R P-1.7$ times more often $(P=0.02$, $\mathrm{x} 2=3.4) ; \mathrm{GH}-2.2$ times more often $(\mathrm{P}=0.03, \mathrm{x} 2=6.3) ; \mathrm{VT}-$ 1.3 times more often $(P=0.01, x 2=4.5)$; $S F-1.2$ times more often $(P=0.03, x 2=3.6) ; R E-1.3$ times more often $(P=0.01$, $\mathrm{x} 2=2.9) ; \mathrm{MH}$, general indicator of positive emotions -1.7 times more often ( $P=0.03, x 2=6.6)$. Thus, it should be noted here that sports has a positive effect on almost all QOL indicators.

\section{CONCLUSIONS}

1. Comparing the self-assessments of the group of students at the first and third years of studying at a higher educational institution, we registered that by the third year there are more students reporting high values for the following QOL indicators: physical functioning (PF); role physical (RP); bodily pain (BP); general health $(\mathrm{GH})$; vitality $(\mathrm{VT})$; social functioning (SF); role emotional (RE); mental health $(\mathrm{MH})$.

\section{Reference}

1. Baranov AA, Al'bickij VYu., Vinyarskaya IV. Izuchenie kachestva zhizni v medicine i pediatrii. Voprosy sovremennoj pediatrii. 2005; 4(2): 7-12. Russian.

2. Kuchma VR i dr. Gigienicheskie problemy organizacii obucheniya v profil'nyx klassax kolledzhej. Gigiena i sanitariya. 2015; 94(4): 8-10. Russian

3. Sergeev RV Molodezh' i studenchestvo kak social'nye gruppy i ob"ekt sociologicheskogo analiza. Vestnik Adygejskogo gosudarstvennogo universiteta. Seriya 1: Regionovedenie: filosofiya, istoriya, sociologiya, yurisprudenciya, politologiya, kul'turologiya. 2010; (1): 12-18. Russian.

4. Mazepina OYu Problemy opredeleniya i izmereniya urovnya kachestva zhizni naseleniya. Kachestvo zhizni i chelovecheskij potencial territorij. 2014; (6): 83-90. Russian.

5. Parenkova IA, Kokolina VF. Kachestvo zhizni $v$ kompleksno ocenke sostoyaniya reproduktivnogo zdorov'ya podrostkov. Pediatriya. 2011; 90 (4): 141-145. Russian.

\section{Литература}

1. Баранов А.А., В.Ю. Альбицкий, И.В. Винярская. Изучение качества жизни в медицине и педиатрии. Вопросы современной педиатрии. 2005;4(2):7-12.

2. Кучма В.Р., Шубочкина Е.И., Ибрагимова Е.М. Гигиенические проблемы организации обучения в просильных классах колледжей. Гигиена и санитария. 2015;94(4):8-10.

3. Сергеев Р.В. Молодежь и студенчество как социальные группы и объект социологического. Вестник Адыгейского государственного университета. Серия 1: Регионоведение: философия, история, социология, юриспруденция, политология, культурология. 2010;1: 12-18.

4. Мазепина О.Ю. Проблемы определения и измерения уровня качества жизни населения. Качество жизни и человеческий потенциал территорий. 2014;(6): 83-90.

5. Паренкова И.А., Коколина В.Ф. Качество жизни в комплексной оценке состояния репродуктивного здоровья подростков. Педиатрия. 2011;90(4):141-145.

6. Петрова Н.А., Янушанец О.И., Мацкевич И.С. Влияние степени адаптированности и образа жизни на качество
2. It was also established that by the third year the number of students with a bad habit of tobacco smoking, use of alcohol and drugs is growing. Bad habits cause significant deterioration of the QOL indicators, such as PF, RP, GH, $\mathrm{VT}, \mathrm{RE}$ and $\mathrm{MH}$.

3. By the third year, fewer students went in for sports as extracurricular activity. Sports significantly improve such QOL indicators as PF, RP, GH, VT, RE, MH.

4. It was found that over three years of study, the proportion of students who are able to quickly and adequately respond to the changing conditions around them has decreased by 4.8 times. The number of students who have difficulty communicating with peers and teachers has increased. However, the share of students who are completely maladapted has decreased.

5. The level of adaptability has a statistically significant effect on such QOL criteria as PF, GH, SF and $\mathrm{MH}$.

6. This research enabled development of recommendations aimed at identifying students running risks of maladaptation and illnesses with the aim to render such students targeted medical and psychological assistance and adjust the sanitary and epidemiological conditions of studying.

6. Petrova NA, Yanushanec OI, Mackevich IS. Vliyanie stepeni adaptirovannosti i obraza zhizni na kachestvo zhizni pervokursnikov mediko-profilakticheskogo fakul'teta medicinskogo universiteta. Zdorov'e naseleniya i kachestvo zhizni: e'lektronnyj sbornik materialov VII Vserossijskoj s mezhdunarodnym uchastiem zaochnoj nauchno-prakticheskoj konferencii. SPb. 2020; (2): 332 s. Russian.

7. Kuchma VR, red. Sbornik «Gigiena detej i podrostkov. Sbornik normativno-metodicheskix dokumentov» M.: NCZD RAMN. 2013; 379 s. Russian.

8. Shubochkina El, Ibragimova EM, Ivanov VYu, Blinova EG, Novikova II, Yanushanec OI, Alekseeva EA. Rezul'taty mnogocentrovyx issledovanij kachestva i obraza zhizni yunoshej, obuchayushhixsya v kolledzhax. ZNiSO. 2016; 8: 281. Russian.

9. Shubochkina El, Ibragimova EM, Ivanov VYu. et al. To usage of life quality indicators in hygiene research. Mater. 17 sezda pediatrov (Moskva, 14-17 fevralya 2013). ABS (66). Russian.

жизни первокурсников медико-профилактического факультета медицинского университета. Здоровье населения и качество жизни: электронный сборник материалов VII Всероссийской с международным участием заочной научно-практической конференции под редакцией З.Д.Н. РФ, проф. В.С. Лучкевича.- СПб., 2020; 2: 332 c.

7. Кучма В.Р., ред. Сборник «Гигиена детей и подростков. Сборник нормативно-методических документов» М.: НЦЗД PAMH; 2013; 379 c.

8. Шубочкина Е.И., Ибрагимова Е.М., Иванов В.Ю., Блинова Е.Г., Новикова И.И., Янушанец О.И., Алексеева Е.А. Результаты многоцентровых исследований качества и образа жизни юношей, обучающихся в колледжах. ЗНиСО. 2016;8: 281.

9. Shubochkina E.I., Ibragimova E.M., Ivanov V. Yu. et al. To usage of life quality indicators in hygiene research. Матер. 17 съезда педиатров (Москва, 14-17 февраля 2013). ABS (66). 